\title{
Molecular Docking terhadap Senyawa Isoeleutherin dan Isoeleutherol sebagai Penghambat Pertumbuhan SARS-CoV-2
}

\author{
Nathanael F. Prasetio, ${ }^{1}$ Billy J, Kepel, ${ }^{2}$ Widdhi Bodhi, ${ }^{2}$ Fatimawali, ${ }^{2}$ \\ Aaltje Manampiring, ${ }^{2}$ Fona Budiarso ${ }^{2}$
}

\author{
${ }^{1}$ Program Studi Pendidikan Dokter Fakultas Kedokteran Universitas Sam Ratulangi, \\ Manado, Indonesia. \\ ${ }^{2}$ Bagian Kimia Fakultas Kedokteran Universitas Sam Ratulangi, Manado, Indonesia \\ Email: nathanael.prasetio@gmail.com
}

\begin{abstract}
Dayak onions are herbal plants used by Indonesians as an antiinflammatory, anticancer, antimicrobial, antidiabetic, antihypertensive and antiviral. By consuming herbal plants, it can increase immunity which is the main key in preventing the virus, especially COVID-19. This study was aimed to determine the effect of dayak active compound anchoring on the growth of the corona virus. This study used molecular docking method. The results of visualization of molecular docking when compared to the binding affinity of remdesivir obtained a binding affinity of -7.3 , while the binding affinity of isoeleutherin and isoeleutherol was -6.9 , so the result was lower than remdesivir. isoeleutherin and isoeleutherol compounds have a lower binding affinity value than remdesivir, so isoeleutherin and isoeleutherol compounds have lower yields as inhibitors of COVID-19.
\end{abstract}

Keywords: dayak onions, SARS-CoV-2, molecular docking

\begin{abstract}
Abstrak: Bawang Dayak merupakan tanaman herbal yang digunakan masyarakat Indonesia sebagai antiinflamasi, antikanker, antimikroba, antidiabetes, antihipertensi dan antivirus. Dengan mengkonsumsi tanaman herbal dapat meningkatkan kekebalan tubuh yang menjadi kunci utama dalam mencegah virus terlebih COVID-19. Penelitian ini bertujuan untuk mengetahui pengaruh penambatan senyawa aktif bawang dayak terhadap pertumbuhan dari corona virus. Jenis penelitian ini menggunakan metode penelitian penambatan molekul (molecular docking). Hasil visualisasi molecular docking jika dibandingkan binding affinity dari remdesivir didapatkan binding affinity yaitu $-7,3$ sedangkan binding affinity dari isoeleutherin dan isoeleutherol adalah $-6,9$, maka diperoleh hasil yang lebih rendah dari remdesivir. senyawa isoeleutherine dan isoeleutherol memiliki nilai binding affinity yang lebih rendah dari remdesivir, maka senyawa isoeleutherin dan isoeleutherol memiliki hasil yang lebih rendah sebagai penghambat COVID-19.
\end{abstract}

Kata Kunci: bawang dayak, SARS-CoV-2, molecular docking

\section{PENDAHULUAN}

Tanaman obat tradisional merupakan tanaman yang sangat popular untuk dimanfaatkan sebagai bahan baku obat tradisional. Konsumsi atau penggunaan tanaman obat dipercaya akan meningkat- kan daya tahan tubuh (memperbaiki immune system). ${ }^{1}$ Organisasi kesehatan dunia mendukung upaya peningkatan kebijakan, keamanan, efikasi, kualitas, dan khasiat dari obat tradisional. ${ }^{2}$ Bawang Dayak (Eleutherine palmifolia (L.) Merr) 
merupakan tanaman khas Kalimantan Tengah. Tanaman ini sudah secara turun temurun dipergunakan masyarakat Dayak sebagai tanaman obat. ${ }^{3}$

COVID-19 menjadi wabah yang meresahkan dikarenakan penyebarannya yang terjadi dengan sangat cepat melalui kontak antara manusia dengan manusia. Sehingga jumlah penderita terkonfirmasi secara drastis meningkat dalam waktu yang singkat. Namun Kemenkes menyatakan bahwa pemulihan dari infeksi virus ini dapat dilakukan tanpa perawatan khusus, jika sistem imun seseorang kuat, karena virus bersifat self medication. ${ }^{4}$ Sistem imun merupakan mekanisme pertahanan tubuh yang akan melindungi tubuh dari infeksi bakteri, virus, hingga parasite, serta mengeliminasi zat asing lain dari tubuh. ${ }^{5}$ Untuk itu pada masa ini sangat penting bagi masyarakat untuk menjaga sistem imun agar tetap kuat untuk menjaga tubuh dari infeksi virus. ${ }^{6}$

Penambatan molekuler adalah studi yang mempelajari bagaimana dua atau lebih struktur molekul dapat berikatan satu sama lain, dengan kata lain memecahkan masalah secara 3 dimensi. $^{7}$ Penambatan molekular adalah alat dalam biologi molekular struktural dan penemuan obat berbasis struktur. Tujuan dari penambatan ligan-protein adalah untuk memahami dan memprediksi pengenalan molekular, menemukan kemungkinan mode ikatan dan memprediksi afinitas pengikatan. ${ }^{8}$

Berdasarkan latar belakang tersebut, peneliti tertarik untuk melakukan "molecular docking" dari senyawa aktif yang berada di dalam bawang dayak untuk dilakukan penambatan terhadap main protease dari SARS-CoV 2.

\section{METODE PENELITIAN}

Penelitian ini di mulai pada bulan September 2020 - Desember 2020. Tempat pembuatan penambatan molekul senyawa aktif umbi bawang dayak (Eleutherine palmifolia (L.) Merr) pada main protease covid-19 dilakukan di Fakultas Kedokteran Universitas Sam
Ratulangi Manado. Sampel umbi bawang dayak (Eleutherine palmifolia (L.) Merr) yang mengandung senyawa naftokuinon dan turunannya yaitu eleutherin dan eleutherol, yang diambil di kelurahan Tuutu, Kecamatan Tondano Barat, Kabupaten Minahasa, Sulawesi Utara (Gambar 1).

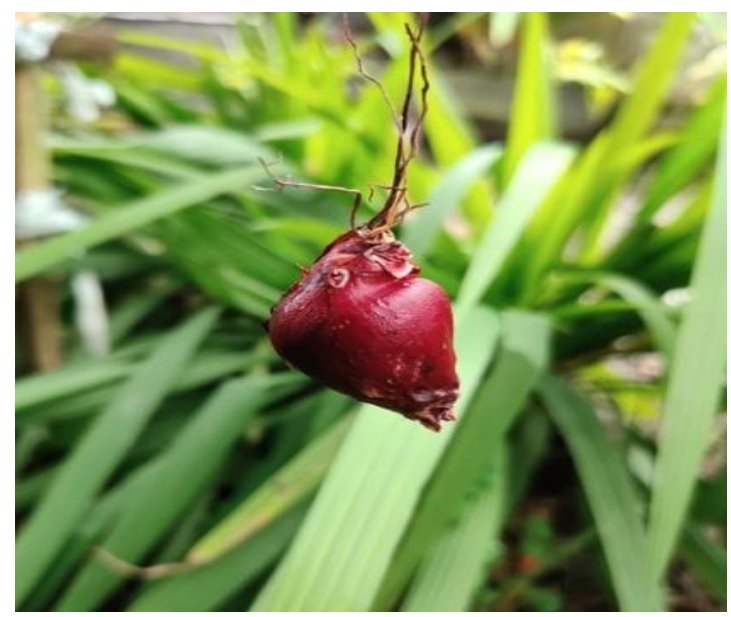

Gambar 1. Umbi Bawang Dayak (Eleutherine palmifolia (L.) Merr) diambil di kelurahan Tuutu, Kecamatan Tondano Barat, Kabupaten Minahasa, Sulawesi Utara

Dengan melakukan penambatan molekul senyawa aktif umbi bawang dayak pada protein spike SARS-CoV 2 diharapkan dapat terlihat seberapa besar efek dari umbi bawang dayak ini sebagai tumbuhan obat penghambat pertumbuhan coronavirus.

Alat perangkat keras yang di gunakan adalah Laptop Acer Aspire E dengan spesifikasi OS: Windows 8.1, Processor AMD A-Series Quad Core Processor A10-7300 (4 MB L2 cache, RAM 16 GB DDR3L SDRAM. Perangkat lunaknya menggunakan 4 aplikasi yaitu autodock tools/MGL tools, autodock vina, open babel, dan biovia discovery studio 2020 .

Bahan-bahan yang digunakan adalah website protein data bank (https://www.rcsb.org) dan PubChem (https://pubchem.ncbi.nlm.nih.gov)

Persiapan senyawa pada tanaman bawang dayak yang akan dijadikan ligan diperoleh melalui situs website Pubchem 
kemudian download dengan format SDF 3 D. Selanjutnya buka aplikasi open babel untuk mengubah format SDF menjadi PDB.

Persiapan Reseptor Covid-19 diperoleh melalui situs website PDB (Protein data bank), kemudian download dengan format PDB. Selanjutnya buka aplikasi Discovery studio visualisasi untuk membersikan reseptor yang masih kotor. Langkah pertama klik menu script kemudian pilih selection selanjutnya select water molekul dan yang terakhir tekan delete pada keyboard. Langkah kedua yaitu klik menu script kemudian pilih selection selanjunya select ligan kemudian delete. Jika reseptor sudah bersih secara keseluruhan, Langkah terakhir tekan pada menu file kemudian save as reseptor tersebut dalam format PDB.

Proses molekuler docking menggunakan aplikasi Autodock tools dan Autodock vina. Struktur reseptor dan ligan yang telah di optimasi secara terpisah disimpan dalam satu folder yang sama. Untuk molekular docking menggunakan autodock tools terlebih dahulu dengan mempersiapkan reseptor tahapan sebagai berikut : Dibuka aplikasi autodock tools kemudian klik read moleculer pada menu file dan pilih reseptor yang akan di docking. Reseptor yang sudah ada ditambahkan dengan hydrogen dan centang pada pilihan all hydrogen, method no Bond order, yes renumber atom include new hydrogen, kemudian klik OK. Setelah reseptor sudah ketambahan hydrogen, klik grid macromolekuler kemudian klik choose lalu klik reseptor dan terakhir select molekul. Reseptor yang disimpan formatnya dalam bentuk PDBQT. Selanjutnya untuk persiapan ligannya, tahapannya sebagai berikut : klik ligan kemudian klik input baru klik open dan pilih ligan yang ada pada folder. Selanjutnya jika ligan sudah keluar pada layer kerja klik torsion tree untuk mengatur number of torsion pada ligan, selanjutnya simpan ligan dalam format PDBQT.

Langkah selanjutnya yaitu mempersiapkan tempat dimana ligan akan menambat pada reseptor dengan langkah sebagai berikut: pilih reseptor format PDBQT kemudian klik grid box pada menu grid, selanjutnya sesuaikan number of point pada sumbuh x (merah), y (hijau), z (biru). Buka Discovery studio visualisasi untuk melihat sisi aktif atau tempat penambatan area reseptor tersebut kemudian klik kanan dan mencari sampai area tersebut di temukan. Selanjutnya buka Kembali aplikasi Autodock tools dan masukan nilai $\mathrm{x}, \mathrm{y}, \mathrm{z}$ yang ditemukan pada reseptor di Discovery studio visualisasi.

Langkah selanjutnya buka aplikasi Notepad dan masukan data data seperti reseptor, ligan, center $\mathrm{x}$, center $\mathrm{y}$, center $\mathrm{z}$, size $\mathrm{x}$, size $\mathrm{y}$, size $\mathrm{z}$ dan keakuratan (Gambar 2).

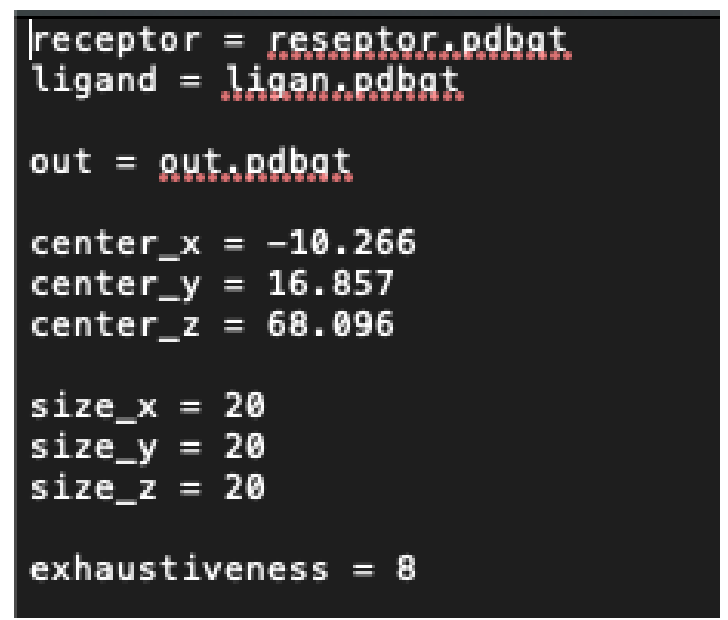

Gambar 2. Format notepad masukan data-data seperti reseptor, ligan, center $\mathrm{x}$, center $\mathrm{y}$, center $\mathrm{z}$, size $\mathrm{x}$, size $\mathrm{y}$, size $\mathrm{z}$ dan keakuratan

Kemudian save di folder yang telah dibuat. Selanjutnya masukan aplikasi autodock vina yang terdiri dari vina, vina split dan vina license pada folder yang telah dibuat, kemudian buka aplikasi Command prompt/terminal dan masukan format (contoh: C:Iuser\Costumer> D:I cd vina..), lalu masukan rumus untuk perhitungan dalam command prompt :

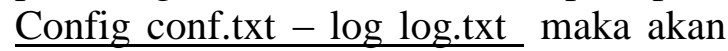


muncul hasil binding affinity dari ligan yang diteliti. Setelah itu gunakan vina split untuk memisahkan hasil dari ligan satu per satu dengan menggunakan rumus D:Ivina>vina-split .. input out. pdbqt. Tahap terakhir yaitu visualisasi dengan cara drag reseptor dan out ligan 1 di Discovery studio visualisasi kemudian dilihat hasilnya dalam bentuk 2D dan 3Dnya.

Aturan Lipinski tersebut adalah molekul dapat dilanjutkan simulasi docking apabila (1) berat molekul kurang dari $500 \mathrm{Da},(2)$ nilai $\log \mathrm{P}$ kurang dari 5, (3) jumlah donor ikatan hidrogen kurang dari 5, dan (4) jumlah akseptor ikatan hidrogran kurang dari 10.(9) Tabel 1 memperlihatkan sifat ligan berdasarkan aturan lipinski, Berdasarkan tabel 1 senyawa isoeleutherin dan isoeleutherol memenuhi aturan lipinski karena lebih rendah dari syarat-syarat yang ada dalam aturan lipinski, maka senyawa isoeleutherin dan isoeleutherol dapat digunakan menjadi ligan untuk di tambatkan pada main protease COVID-19 (6LU7) dan memperoleh hasil yang dapat digunakan sebagai calon obat yang baik karena sesuai dengan aturan.

\section{HASIL PENELITIAN}

Dalam penelitian ini untuk mendapatkan ligan sebagai calon obat yang akan dikembangkan maka kriteria obat yang baik harus mengikuti aturan Lipinski (lipinski's Rule of Five) yang dikembangkan oleh Christopher A. Lipinski, Sebelum dilakukan molecular docking perlu dilakukan pengecekan sifat-sifat dari ligan yang digunakan, apakah memenuhi aturan Lipinski.

Tabel 1. Sifat ligan berdasarkan aturan Lipinski

\begin{tabular}{cccccc}
\hline ligand & $\begin{array}{c}\text { Formula } \\
\text { molekul }\end{array}$ & $\begin{array}{c}\text { Berat molekul } \\
(<500 \mathrm{~g} / \mathrm{mol})\end{array}$ & $\operatorname{LogP}(<5)$ & $\begin{array}{c}\text { H-bond donor } \\
(<5)\end{array}$ & $\begin{array}{c}\text { H-bond } \\
\text { acceptor }(<10)\end{array}$ \\
\hline Isoeleutherin & $\mathrm{C}_{16} \mathrm{H}_{16} \mathrm{O}_{4}$ & 272,29 & 2 & 0 & 4 \\
Isoeleutherol & $\mathrm{C}_{14} \mathrm{H}_{12} \mathrm{O} 4$ & 244,24 & 2,6 & 1 & 4 \\
\hline
\end{tabular}

Tabel 2 memperlihatkan hasil Molecular Docking senyawa isoeleutherin dan isoeleutherol dengan main protease COVID-19(6LU7), remdesivir menjadi kontrol positif dalam melakukan penelitian ini. Hasil molecular docking didapatkan senyawa isoeleutherin dan isoeleutherol memiliki binding affinity yang sama yaitu $-6,9$.

Tabel 2. Hasil molecular docking senyawa isoeleutherin dan isoeleutherol dengan main protease SARS-CoV-2 (6LU7)

\begin{tabular}{cc}
\hline Ligand & $\begin{array}{c}\text { Energi Ikatan } \\
(\mathrm{kkal} / \mathrm{mol})\end{array}$ \\
\hline Isoeleutherin & $-6,9$ \\
Isoeleutherol & $-6,9$ \\
\hline
\end{tabular}

Berdasarkan data Computed Atlas of Surface Topography of Proteins main protease dari COVID-19(6LU7) memiliki asam amino residu yaitu THR24, THR25, THR26, LEU27, HIS41, THR45, SER46, MET49, PHE140, LEU141, ASN142, GLY143, SER144, CYS145, HIS163, MET165, GLU166, HIS172.

\section{BAHASAN}

Hasil visualisasi molecular docking Isoeleutherin memiliki ikatan van der Waals dan conventional hydrogen bond untuk isoeleutherol memiliki ikatan conventional hydrogen bond yang terdapat pada hasil molecular docking, visualisasi senyawa isoeleutherin terbentuk pada asam amino residu GLN189, HIS164, MET49, HIS41, THR26, LEU141, ASN142, SER144. Senyawa isoeleutherin terdapat ikatan 
hidrogen yang terbentuk pada asam amino residu GLY143, GLU166, juga interaksi Alkyl/Pi Alkyl Isoeleutherin pada asam amino residu LEU27, MET165, CYS145, untuk senyawa isoeleutherol terdapat ikatan hidrogen yang terbentuk pada asam amino residu GLY143, GLU166, juga interaksi Alkyl/Pi Alkyl isoeleutherol pada asam amino residu LEU27, MET165, CYS145.

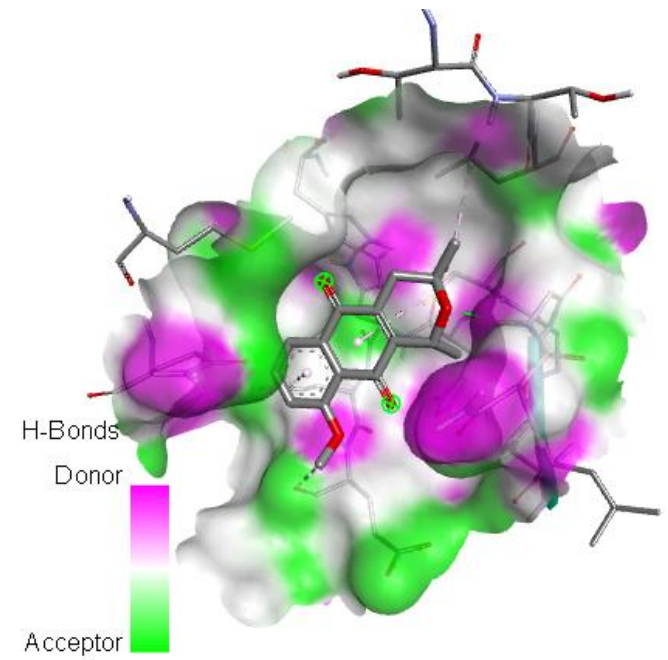

Gambar 3. Visualisasi hasil molecular docking senyawa Isoeleutherin dengan reseptor main protease COVID-19(6LU7) dalam bentuk 3D

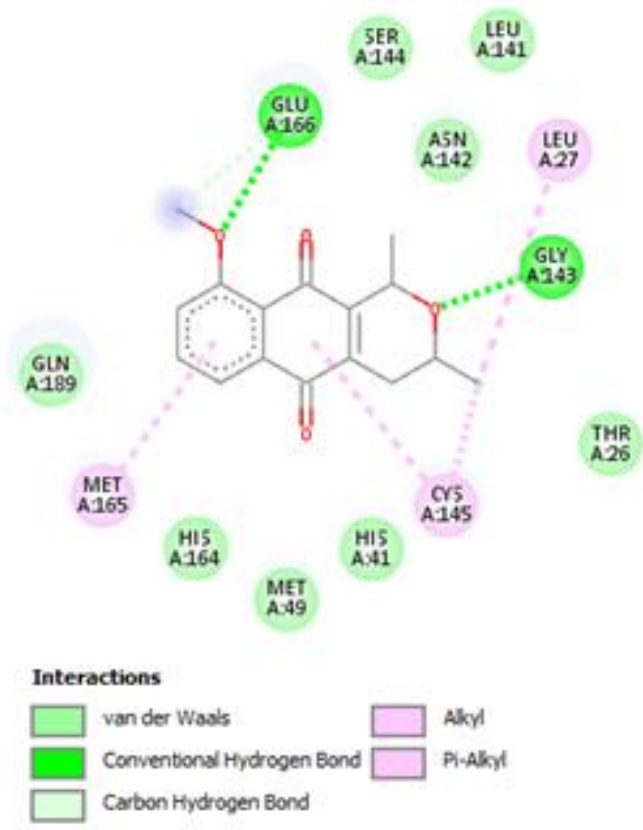

Gambar 4. Visualisasi hasil molecular docking senyawa Isoeleutherin dengan reseptor main protease COVID-19(6LU7) dalam bentuk 2D
Visualisasi hasil molecular docking senyawa Isoeleutherin dengan reseptor main protease COVID-19(6LU7) dalam bentuk 3D dan 2D, pada senyawa Isoeleutherin asam amino residu yang bekerja pada sisi aktif yaitu pada ikatan van der Waals MET49, HIS41, THR26, LEU141, ASN142, SER144, dan ikatan hidrogen bekerja pada sisi aktif GLY143, GLU166, untuk interaksi Alkyl/Pi Alkyl bekerja pada LEU27, MET165, CYS145 (Gambar 3, Gambar 4)

Visualisasi hasil molecular docking senyawa Isoeleutherol dengan reseptor main protease COVID-19(6LU7) dalam bentuk 3D dan 2D, pada senyawa Isoeleutherol asam amino residu yang bekerja pada sisi aktif yaitu ikatan hidrogen GLY143, GLU166, pada interaksi Alkyl/Pi Alkyl bekerja pada sisi aktif LEU27, MET165, CYS145. Dari visualisasi di atas kita dapat melihat asam asam amino yang bekerja pada sisi aktif main protease SARS-CoV 2, isoeleutherin dan isoeleutherol memiliki asam amino yang bekerja pada sisi aktif dari main protease SARS-CoV 2 (Gambar 5, Gambar 6).

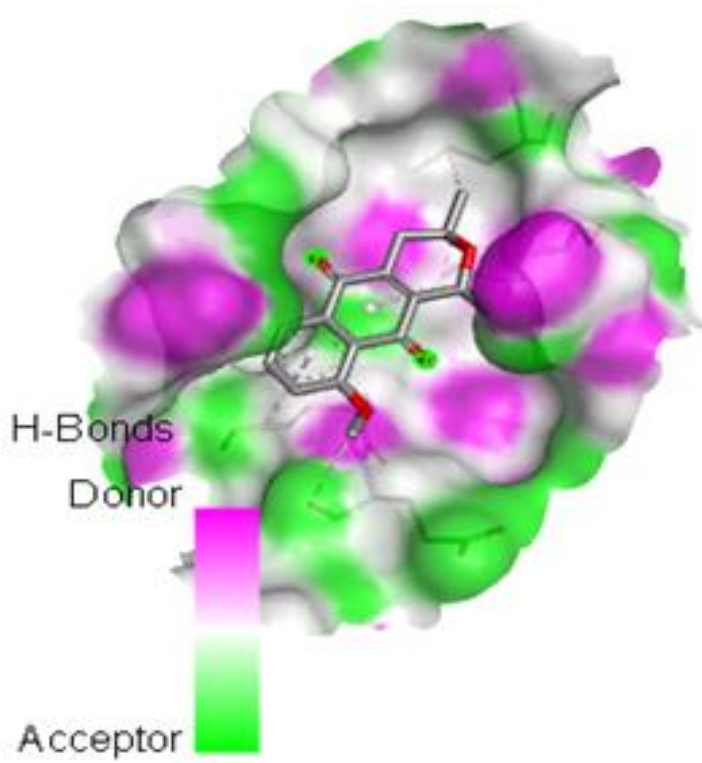

Gambar 5. Visualisasi hasil molecular docking senyawa Isoeleutherol dengan reseptor main protease COVID-19(6LU7) dalam bentuk $3 \mathrm{D}$ 


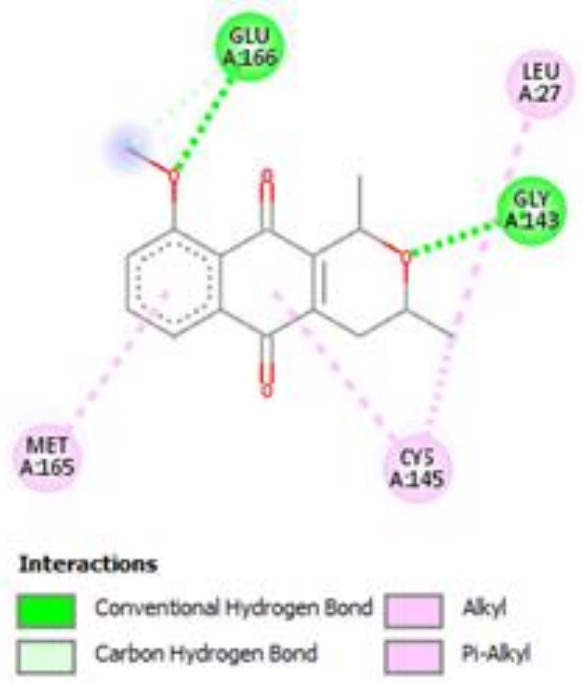

Gambar 6. Visualisasi hasil molecular docking senyawa Isoeleutherol dengan reseptor main protease COVID-19(6LU7) dalam bentuk 2D

\section{SIMPULAN}

Senyawa isoeleutherin memiliki interaksi ikatan van der Waals, ikatan hidrogen dan interaksi Alkyl/Pi Alkyl sedangkan isoeleutherol memiliki ikatan Hidrogen dan interaksi Alkyl/Pi Alkyl dan diperoleh hasil interaksi asam amino residu yang bekerja pada sisi aktif main protease SARS-CoV-2 memiliki nilai binding affinity yang lebih rendah dari remdesivir, maka senyawa isoeleutherin dan isoeleutherol memiliki hasil yang lebih rendah sebagai penghambat COVID-19.

\section{Konflik Kepentingan}

Penulis menyatakan tidak terdapat konflik kepentingan dalam studi ini.

\section{DAFTAR PUSTAKA}

1. Siregar RS, Hadiguna RA, Kamil I, Nazir N, Nofialdi N. Permintaan
Dan Penawaran Tanaman Obat Tradisional Di Provinsi Sumatera Utara. J Tumbuh Obat Indones. 2020;13(1):50-60.

2. World Health Organization. (2013). World health statistics 2013. World Health Organization. 2013.

3. Galingging R. Bawang Dayak (Eleutherine palmifolia) sebagai tanaman obat multifungsi. War Penelit dan Pengemb Tanam Ind. 2009;15(3):2-4.

4. Syahrir A, Rahem A, Prayoga A. Religiosity of pharmacy students of UIN Malang during COVID19 pandemic. J Halal Prod Res. 2020;3(1):25.

5. Aripin I. Pendidikan nilai pada materi konsep sistem imun. J Bio Educ. 2019;4(1):1-11.

6. Susilo A, Rumende CM, Pitoyo CW, Santoso WD, Yulianti M, Herikurniawan $\mathrm{H}$, et al. Coronavirus Disease 2019: Tinjauan Literatur Terkini. Jurnal Penyakit Dalam Indonesia. 2020;7(1):45

7. Bulatović RM. Non-oscillatory damped multi-degree-of-freedom systems. Acta Mech. 2001;151(3-4):23544.

8. Morris GM, Lim-Wilby M. Molecular docking. Methods Mol Biol 2008;443:365-82.

9. Syahputra G, Ambarsari L, Sumaryada T. Simulasi Docking Kurkumin Enol , Bismetoksikurkumin Dan Analognya Sebagai Inhibitor Enzim12-Lipoksigenase. Jurnal Biofisika. 2014;10(1):55-67. 